\title{
ROME MODELS: BETWEEN HISTORY AND REPRESENTATIONS
}

Ivan Esperança Rocha1

\begin{abstract}
Considered a millenarian art, the construction of models has gained in the last decades a special impulse using electronic supports in the area of archeology as well of architecture and engineering. In this text, will be presented and discussed the original and current role of the models in the historical-architectural reconstruction of the city of Rome, especially those created in the first decades of the 20th century by Giuseppe Marcelliani, Paul Bigot and Italo Gismondi.
\end{abstract}

\section{Keywords}

Model; archeology; architecture; history; power; museology.

\section{Resumo}

Considerada uma arte milenar, a construção de maquetes ganha nas últimas décadas um impulso especial dado pelo uso de suportes eletrônicos tanto na área da arqueologia como da arquitetura e engenharia. Neste texto será apresentado e discutido o papel original e atual das maquetes na reconstrução histórico-arquitetônica da cidade de Roma, com destaque para aquelas criadas, nas primeiras décadas do século XX, por Giuseppe Marcelliani, Paul Bigot e Italo Gismondi.

\section{Palavras-chave}

Maquete; arqueologia; arquitetura; história; poder; museologia.

\footnotetext{
1 Associate Professor, São Paulo State University, Assis, Brazil. E-mail: ierocha@uol.com.br
} 
The mode ${ }^{2}$ is considered an ancient art of reproducing or constructing, on a reduced scale, the most different types of objects, among them statues, votive images, private and public buildings, weapons, everyday scenarios, topographies and even whole cities. In the last decades the physical models, elaborated in wood, clay or paper, counted on the new support of electronic virtualization that facilitated not only the elaboration, but also the updates and improvement of the miniaturization projects $^{3}$.

Thus, if we notice in the use of models in the past limits imposed by the technique of elaboration and the extension of its use, the emergence in the last decades of physical and electronic technologies stimulated its largescale use for presentation and advertising of real estate projects and products launched or to be launched on the market, urbanization plans and also for trials on different characteristics of the miniaturized object be it a building, a vehicle, an aircraft - such as its resistance to shocks, inclement weather, earthquakes, and even seaquakes, aiming individual and collective security.

Architectural models, originally developed by artisans, became an integral part of training and work, particularly of engineers and architects. Contemporary architecture and engineering are even interested in the history of models over time, since their earliest appearances in antiquity, as can be seen in Rozestraten's study of the models of Tepe Gawra in Mesopotamia (circa 3500 BC), of Dashur in Egypt (1900-1730 BC), of Arkhanes, Greece (1700-1630 BC) (figure 1), of the Niha temple (2nd century $\mathrm{AD}$ ) and the Baalbek theater (2nd century $\mathrm{AD}$ ), in the Becaa Valley, of Ostia (1st century BC) and of the stadium of Villa Adriana, in Ancient Rome (2nd century AD) ${ }^{4}$.

In a joint effort, historians and architects focused on drawing up models of cities of different times and spaces. We have total or partial models of Jerusalem, Beersheva, Athens, Mecca, Ephesus, Miletus, Merida, London, Brussels, Vienna, New York, Detroit, San Francisco, Dubai, Sydney,

\footnotetext{
2 The french word to model, maquette, comes from the italian word macchieta (sketch) (Houaiss, A. (2001). Dicionário Eletrônico Houaiss. Rio de Janeiro: Objetiva [CD ROM].

${ }^{3}$ Royo, Manuel (2009). Une nouveauté du xxe siècle? Maquettes de Rome et perception « paysagère » de l'histoire. Histoire de l'art, 65:7.

${ }_{4}^{4}$ Rozestraten, Artur Simões (2003). Estudo sobre a história dos modelos arquitetônicos na Antiguidade: origem e características das primeiras maquetes de arquiteto (Unpublished master's thesis). Universidade de S. Paulo, São Paulo, p. I-II.
} 
Shanghai, Brasília, among many others. There are also models of idealized intelligent cities such as Iskandar in Malaysia ${ }^{5}$.

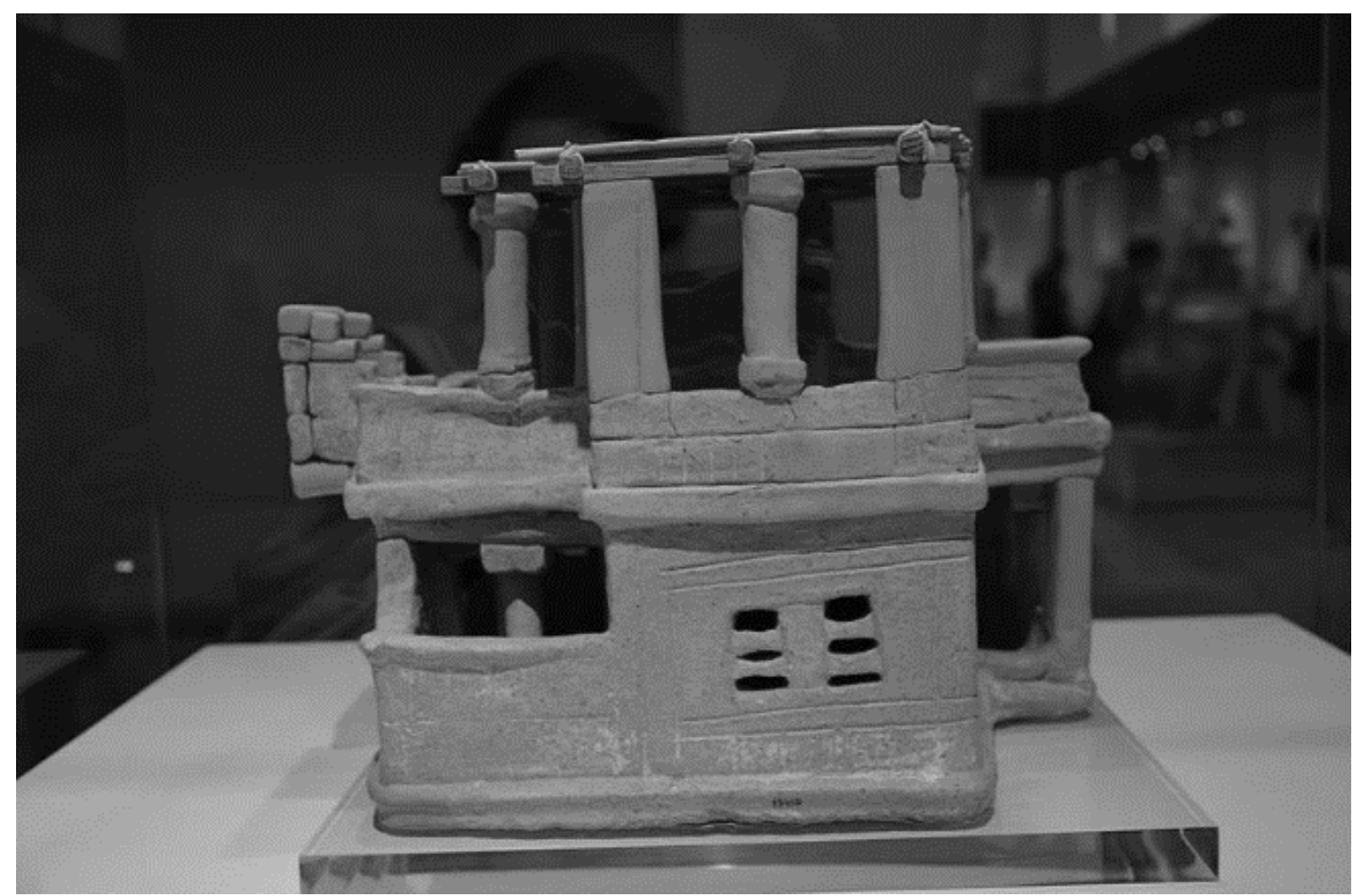

Fig. 1. Model of a house. Arkhanes. Heraklion Archaeological Museum. Greece.

This paper will present and discuss the role of models in the historicalarchitectural reconstruction of the city of Rome, explaining the proximity between history and architecture in its creation. The urban models of the city of Rome are a characteristic of the twentieth century and they incorporate the graphic and artistic heritage gathered between the seventeenth and eighteenth centuries, which includes the tradition of theatrical scenery and historical painting 6 .

These works are initially performed by artisans and represent ruined and unrestored constructions that fed collections of antiquaries such as John Soane and aristocrats such as Frederick Francis I of Mecklenburg, Catherine II of Russia and Gustav III of Sweden7. It must be said that the painters who got involved in the Middle Ages with architectural representations of the past worked on models they never saw, searching

\footnotetext{
Iskandar Malaysia: City Of The Future. Retrieved from http://lankasia.com/content/iskandar-malaysia-city-future. Date of access: 25 oct 2017.

${ }^{6}$ Royo, Manuel, op.cit., p. 7.

7 Royo, Manuel, op. cit., p. 8.
} 
inspiration in available documentary sources and oral tradition, but far from the contributions that would be offered by the archeology ${ }^{8}$.

About the city of Rome, there are three great historical models: the one of the Italian sculptor Giuseppe Marcelliani, realized between 1905 and 1906, in scale 1: 100, that of the French architect Paul Bigot, with a dimension of $70 \mathrm{mt} 2$, in scale of 1: 400, held between 1906 and 1911, preserved at the University of Caen (figure 4), and that of the Italian archaeologist Italo Gismondi, at the scale of 1: 250, representing the city in the Constantine period from the beginning of the fourth century AD, built between 1933 and $1937^{\circ}$ and preserved in the Museo della Civiltà Romana in Rome ${ }^{10}$ (figure 3).

The models of Giuseppe Marcelliani (figure 2) and Paul Bigot were built at a time when Rome gained great visibility becoming, in 1871, the capital of the kingdom of Italy unified under the leadership of Giuseppe Garibaldi.

The model of Italo Gismondi, that had the collaboration of Guglielmo Gatti, Antonio Maria Colini and Paolo Fidenzoni, became an important piece in the great exhibition organized by Mussolini, in 1937, with the purpose of restoring the old prestige of Rome in the commemoration of the two millennia of Emperor Augustus, having been installed in the Palazzo delle Esposizioni11. The model creates an idea of Rome pulitta, for eliminating the enclaves produced in modernity, bringing it back to its originality. At that moment, the only model with a reconstruction of Rome was the one already mentioned, of Giuseppe Marcelliani, who was at that moment dismantled ${ }^{12}$.

\footnotetext{
8 Carpo, Mario (2001). How to you imitate a building that you have never seen? Printed images, Ancient Models. Zeitschrift für Kunstgeschichte, 64 bd, 2: 224.

${ }_{9}^{9}$ Italo Gismondi worked in this model until 1971.

10 Such models have a modular structure and received changes from their authors: that of G. Marcelliani, from 1904 to 1910, that of Paul Bigot, from 1904 to 1942 and that of Italo Gismondi, from 1937 to 1973. The Museo della Civiltà Romana is currently closed for renovation (Constantini, Valeria (2017 august 9). Museo della Civiltà Romana assediato da rave party e rifiuti. Corriere della Sera. Edition of Rome). The space of the model is this Museum is said to be not very suitable and inviting (Pasqualini, Anna (2006). L'antiquaria di gesso: passato e futuro del Museo della Civiltà romana all'Eur. Mediterraneo Antico, ix, 2:9.

${ }_{11}$ Pedro Paulo Funari discusses the possible relations between archeology and power (Arqueologia. São Paulo: Contexto, 2003, p. 69-75).

12 Royo, Manuel, op. cit., p.10-14. Liberati, Anna Maria (2003). La rappresentazione di Roma antica nel plastico di Gismondi del Museo della Civiltà Romana a Roma. Cahier de la MRSH, 33:243-44. ELLIS, D.B. (1999). Eternal city. Greece E Rome, 6, 2:191.
} 
Gismondi's original model went through several modifications made by its own author, but it is argued that some of its sections need to undergo radical changes 13 , that can now be facilitated by available electronic resources.

Several exhibitions were organized around the theme of architecture and models, with direct and indirect contributions of countless researchers that were recorded in publications. Lambert highlights the importance of two of them: the first, held in 1994 in Venice (later taken to Washington, Paris, and Berlin), which awarded great names from Brunelleschi to Miguelangel; the second held in 1997 in Turin (later taken to Montreal, Washington and Marseilles) celebrating the baroque and classical periods, having been given a prominent place for the models in the activity of the architects $^{14}$. Regarding these congresses, Lambert highlights one of them that had the theme "Architectural models, function and evolution of an instrument of creation and accomplishment", in which the importance of the role of the models in the architecture was affirmed. In it the authors discussed, among other subjects, the architectural models and projects of antiquity (Alessando Pierattini); function and evolution of the models (Christoph Luitpold Frommel); architectural models in Germany during the Renaissance (Stefan Hoppe); Architectural models in Spain during and after the Renaissance (Pedro Antonio Galera Andreu); models in the Netherlands between 1500-1700 (Marlijn Hurx \& Konrad Ottenheym); the tomb of Rousseau in the Pantheon as architectural model of the Vitruvian temple (Eleonora Guzzo); the reason for the emergence of models under the Empire (Jean-Michel Leniaud); approximations between drawing and model (Benjamin Mouton), among others ${ }^{15}$. This is only a sampling of the effervescence of research around the models in their relationship with architecture, history and culture in general.

One of the issues discussed in these texts was the emergence of professionals specialized in the construction of models to supply the deficient training of architects in this sector, and a doubt that, faced with an exponential growth of means of conception and representation, the

\footnotetext{
13 Liberati, Anna Maria, op. cit., p. 248.

${ }^{14}$ Lambert, Guy (2016). Le maquettes d'architecture. Publications récents. État de la récherche. Archiscopie, 2:94.

15 Lambert, Guy,op.cit., p.91-96, 2016; Fromm, Sabine (2015). Les maquettes d'architecture: fonction et évolution d'un instrument de conception et de réalisation. Paris: Picard; Roma: Campisano Editore, p. 1-11.
} 
physical model could, eventually, have lost their place, despite the great potential of creativity to be invested in its creation ${ }^{16}$.

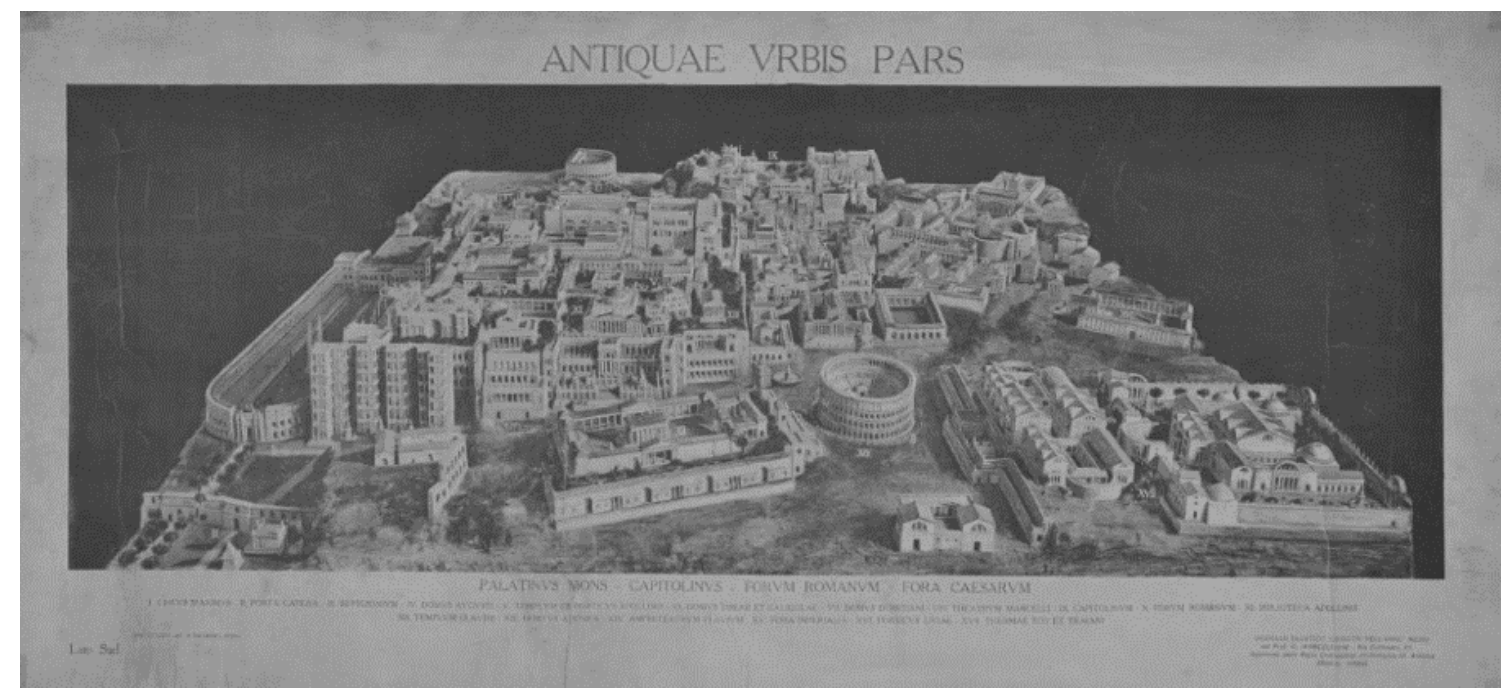

Fig. 2. Model of Rome by Giuseppe Marcelliani, 1905 and 1906. Museo della Civiltà Romana.

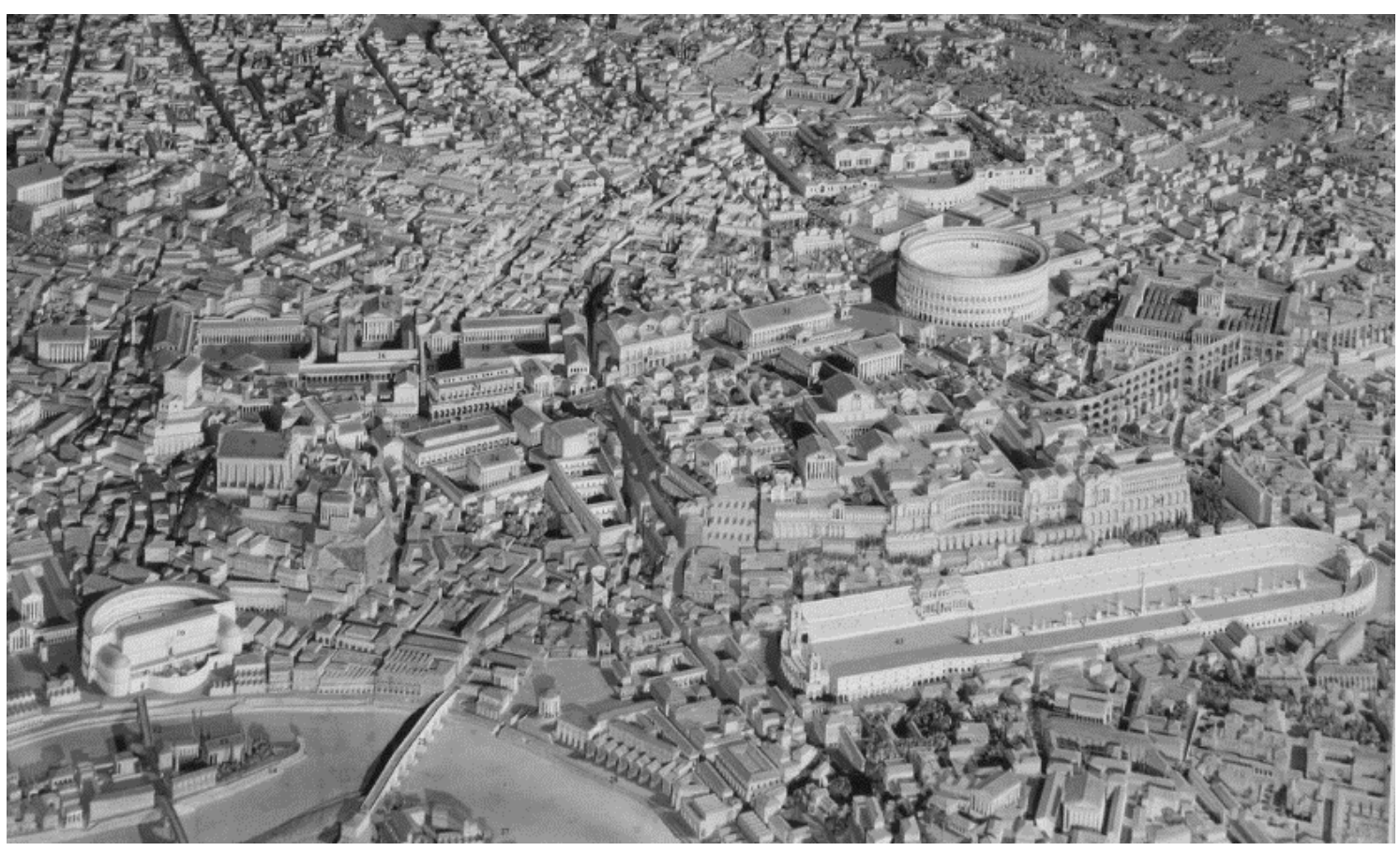

Fig. 3. Model of Rome by Italo Gismondi, 1933 and 1937. Museum of Civiltà Romana.

${ }^{16}$ Lambert, Guy, op.cit., p. 95. 


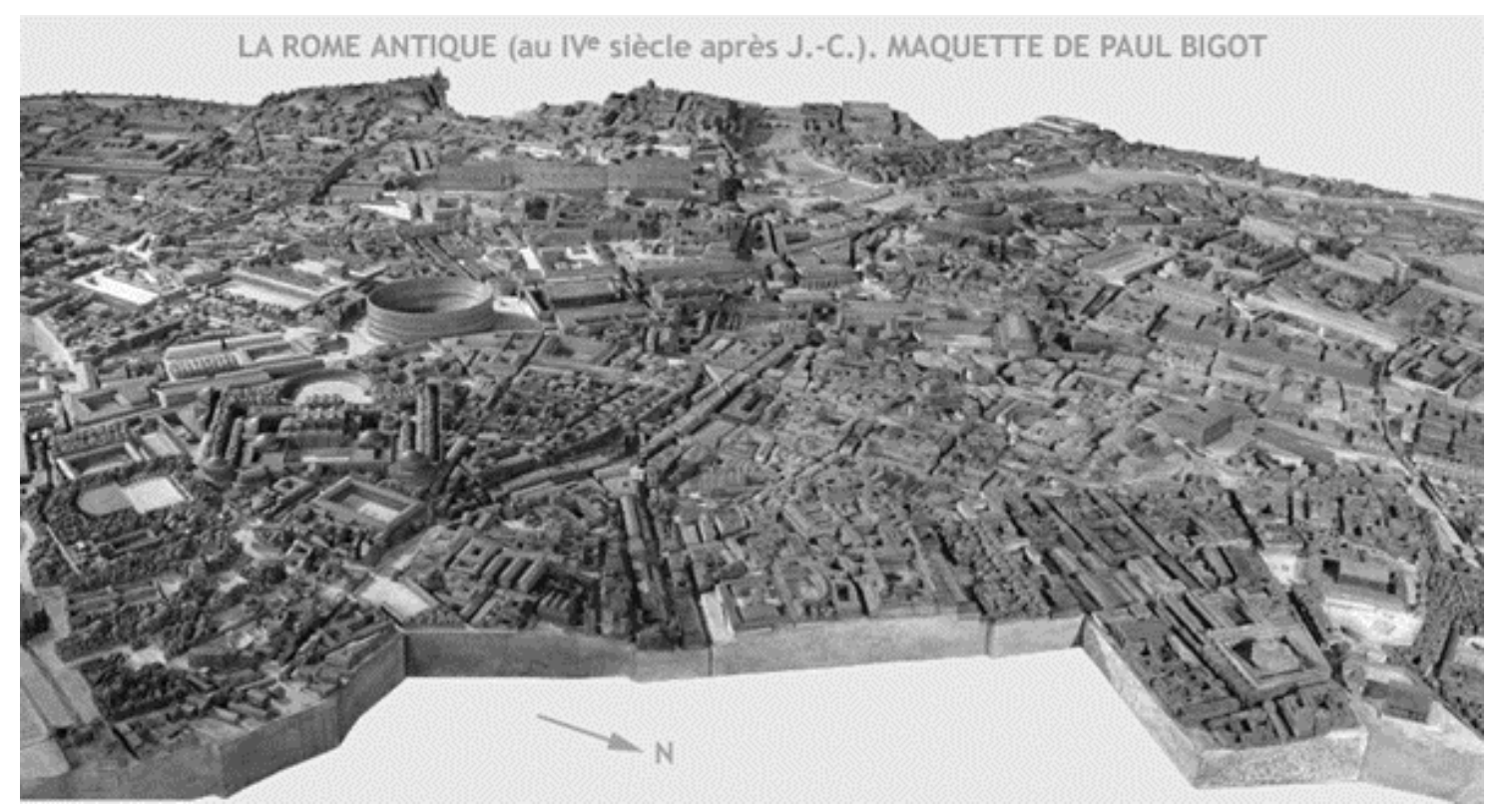

Fig. 4. Rome model Paul Bigot, 1906-1911. University of Caen, France.

If models can already be found in antiquity, they cannot always be considered as prototypes of a construction, and may play other roles such as votive offerings, as in the case of deities or small-scale temples ${ }^{17}$. Regarding the stadium model of the Villa Adriana, II AD, although this villa was built by the Emperor Hadrian with the comforts of a city, with its palaces, theaters and gardens, there is no sign of the presence of a stadium in the place, as might indicate the model of a stadium found there. Furthermore, except the Domitian stadium built in Campus Martius in Rome, the other known examples of Roman stadiums are located in Greece, Asia Minor and the Near East.

Regarding the Gismondi model, the topographic basis used in its realization was what remained of the Vrbis Seueriana, a large map carved in marble, from the time of Septimius Severus (145-211 AD). It was also used the Rodolfo Lanciani's Forma Vrbis Romae, drawn up between 1893 and 1901, and that was a synthesis of the old and new discoveries that occurred at the end of the 19th century on the occasion of the work done at the time when Rome was defined as the capital of the kingdom of Italy, at a moment when new topographic data were collected during the demolitions carried out by the fascist regime, in view of the isolation of the space of the Augustinian monuments, among which the Ara Pacis stood out. For the reconstruction of residential spaces, Gismondi used information obtained in his excavations in Ostia, located in the environs

17Maligorne, Y., Chevet, P., Ferrette, R. (2010). Deux maquettes architecturales récemment découvertes à Rennes. Latomus, 69:99.117. 
of Rome ${ }^{18}$. Many changes need to be made in the model according new discoveries in different areas of the city, such as in the Imperial Forums, however, due to the high costs of modifications, it has been suggested that they can be made with more modern and practical electronic resources ${ }^{19}$, such the example of Bigot's model in Caen, France.

Regarding the virtualization of models of Rome ${ }^{20}$, two projects stand out currently. A first, the project of the University of Caien, France, started in 1994, based on the model that Paul Bigot (figure 5) builds between 19061911 and that he wanted to update in the late 1930s, using archaeology news, but what could not be realized due to World War II and his death on June $8,1942^{21}$, to which must to be added the international project Rome Reborn with the same objective, developed by the University of Virginia, USA, since 1997. In both cases, there is a concern to update the Bigot model using up-to-date archeology news 22 .

The Caien project seeks to create an interactive virtual model of the entire city of Rome, proposing a reconstitution of exterior spaces (streets, houses, shops, public monuments, water supply networks, etc.) and a part of interior spaces (most popular public spaces, and some examples of housing and commercial areas). Water lifting systems, water mills, measuring instruments, war machines are also being reconstituted. The textual, archaeological and iconographic sources used in the construction of the model can also be accessed virtually ${ }^{23}$.

\footnotetext{
18 Libertati, Anna Maria, op. cit, p. 244-246.

${ }^{19}$ Idem, p. 248-250.

20 Unlike what is currently happening with the model of Italo Gismondi, the model of Caen, thanks to the policy of valorization of the work, attracts many visits and is the object of studies and congresses (PASQUALINI, Anna, op.cit., p. 6, note 23).

21 Paul Bigot: un normande à Rome. Retrieved from www.unicaen.fr/cireve/rome/pdr_maquette

.php?fichier=bigot. Date of access: 26 oct. 2017.

22 This because that there are permanent changes in the evidences of archaeology, (Funari, Pedro P. Arqueologia. São Paulo: Contexto, 2003. Reviewed by Orser Jr, Charles E. Mneme, v.6, n.13, dez/2014-jan 2005, p. 98), that is, archaeology must be interpreted as a science under construction (Funari, Pedro P. Arqueologia. São Paulo: Contexto, 2003, p.9)

${ }^{23}$ Fleury, Philippe (2014). Le Plan de Rome de Paul Bigot. De la maquette en plâtre de Paul Bigot à la maquette virtuelle de l'Université de Caen. Civiltà Romana, 1:118-119. There are, currently, two physical copies of this model, the original one is in Caien and a copy, with color interventions, in the Royal Museums of Art and History of Brussels, besides a partial bronze project that is in the Institute of Art and Archaeology of Paris (figure 6).
} 


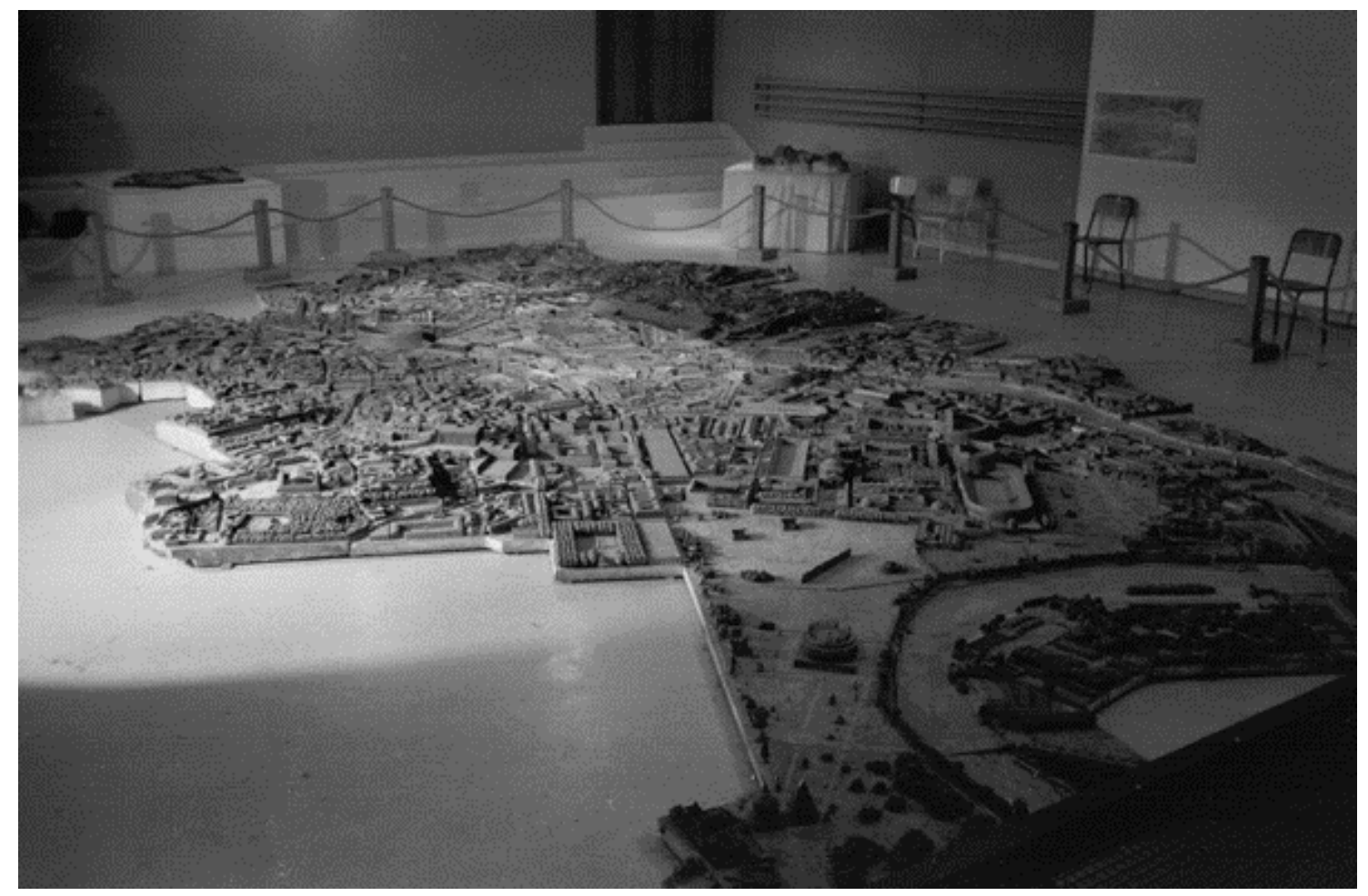

Fig. 5. Paul Bigot's Rome model, 1906-1911. University of Caen, France

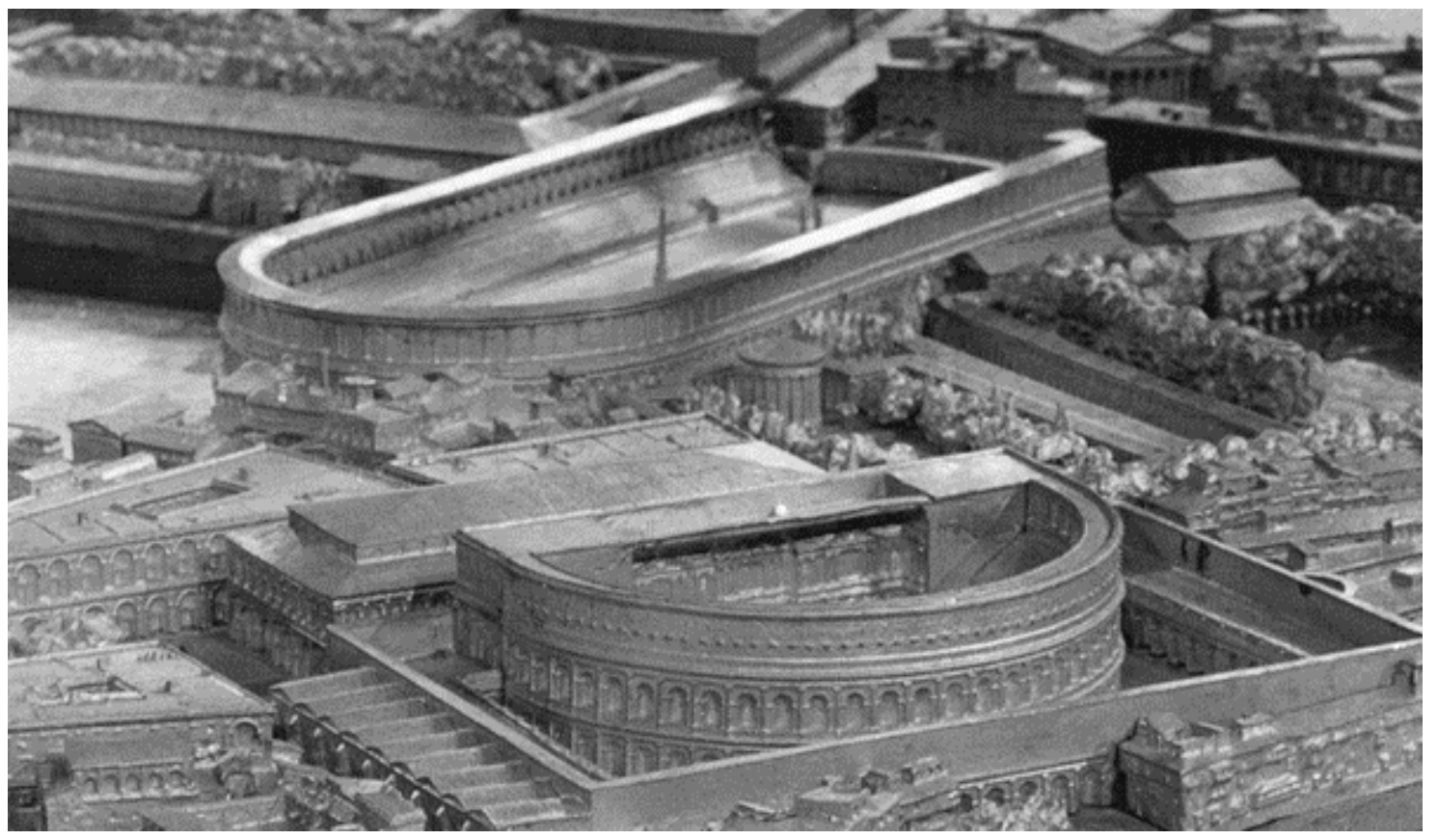

Fig. 6. The Balbus theater and the Circus Flaminius in the Paul Bigot's partial model in bronze. University of Caen, France. 
The methodology used included information on each type of construction available in all Latin and Greek texts, as well as in epigraphy. For the modeling of the Theatre of Pompey were used 93 latin texts and 18 greek texts. The analysis of the sources counted on the collaboration of scholars on greco-roman literature, historians of antiquity, archaeologists and architects, with some of them represented in the committee of monitoring and validation of the work 24 .

In relation to the Rome Reborn project, there is an enlargement in terms of the dating of the reconstructed monuments: it intends to cover the period from $1000 \mathrm{BC}$ to the beginning of the medieval period. The project includes two types of reconstructions: one that refers to a limited number of buildings for which detailed information is available and another of approximately 6750 buildings about them there are only few information. The main software used for the virtualization of monuments is the CityEngine that allows different types of visualization and detailing of the models, complemented by other resources of creation of virtual reality 25 .

In conclusion, we can say that the Rome models, in particular that of Paul de Bigot, which inspired the projects of the University of Caien and the University of Virginia, and that by dynamically incorporating information from archaeological discoveries, become an important pedagogic support for the study of Roman society and its urban structures of the period to which they refer. They create an overview of the architecture of the city of Rome that could hardly be glimpsed in the isolated and partial observation of the ruins of some of its buildings. However, hypothetical may be some of the reconstructions of Bigot's model, the fact that they can be continually updated in these two projects - which tend to multiply - using the available electronic resources avoid the common stereotypes of the physical models of Rome of Marcelliani and Gismondi.

\footnotetext{
${ }^{24}$ FLEURY, Philippe, MADELEINE, Sophie (2009). L'accès aux sources anciennes sur le modèle virtuel de la Rome antique. Schaedae, 22, 3:8.

${ }^{25}$ DYLLA, Kimberly et al. Rome Reborn 2.0: A Case Study of Virtual City Reconstruction Using Procedural Modeling Techniques. Charlottesville: Virginia University. Retrieved from http://romereborn.virginia.edu. Date of accesss: 26 oct. 2017.
} 


\section{Bibliographic references}

CARPO, Mario (2001). How to you imitate a building that you have never seen? Printed images, Ancient Models. Zeitschrift für Kunstgeschichte, 64 bd, 2:223-233.

CHENNAOUI, Youcef, JUAN-VIDAL, Francisco, FANTINI, Filippo (2012). Architectural models and urban planning From Hadrian's Villa maquette to the amphitheater of Caesarea of Mauretania, presented at International Conference on Cultural Heritage and News Technologies, Vienna, 2012, Vienna: Museen der Stadt Wien, p. 1-19.

COSTANTINI, Valeria (2017 august 9). Museo della Civiltà Romana assediato da rave party e rifiuti. Corriere della Sera. Edition of Rome.

DYLLA, Kimberly et al. Rome Reborn 2.0: A Case Study of Virtual City Reconstruction Using Procedural Modeling Techniques Charlottesville: Virginia University. Retrieved from http://romereborn.virginia.edu. Date of access: 26 oct. 2017.

ELLIS, D.B. (1999) Eternal city. Greece \& Rome, 6, 2:189-192.

FLEURY, Philippe, MADELEINE, Sophie. (2009). L'accès aux sources anciennes sur le modèle virtuel de la Rome antique. Schaedae, 22, 3:4-18.

FLEURY, Philippe (2014). Le Plan de Rome de Paul Bigot. De la maquette en plâtre de Paul Bigot à la maquette virtuelle de l'Université de Caen. Civiltà Romana, 1:109-124.

FROMM, Sabine (2015). Les maquettes d'architecture: fonction et évolution d'un instrument de conception et de réalisation. Paris: Picard; Roma: Campisano Editore.

FUNARI, Pedro P. Arqueologia. São Paulo: Contexto, 2003.

FUNARI, Pedro P. Arqueologia. São Paulo: Contexto, 2003. Reviewed by ORSER JR, Charles E. Mneme, v.6, n.13, dez/2014-jan 2005, p. 97-99.

HOUAISS, A. (2001). Dicionário Eletrônico Houaiss. Rio de Janeiro: Objetiva [CD ROM].

ISKANDAR MALAYSIA: City of The Future. Retrieved from http://lankasia.com/content/iskandar-malaysia-city-future. Date of access: 25 oct 2017 . 
LAMBERT, Guy (2016). Le maquettes d'architecture. Publications récents. État de la récherche. Archiscopie, 2:91-96.

LIBERATI, Anna Maria (2003). La rappresentazione di Roma antica nel plastico di Gismondi del Museo della Civilà Romana a Roma. Cahier de la MRSH, 33:243-22.

MALIGORNE, Y., CHEVET, P., FERRETTE, R. (2010). Deux maquettes architecturales récemment découvertes à Rennes. Latomus, 69:99-126.

PASQUALINI, Anna (2006). L'antiquaria di gesso: passato e futuro del Museo della Civiltà romana all'Eur. Mediterraneo Antico, v. ix, 2:1-16.

PAUL BIGOT: un normande à Rome. Retrieved from www.unicaen.fr. Date of access: 26 oct. 2017.

ROYO, Manuel (2009). Une nouveauté du xxe siècle? Maquettes de Rome et perception " paysagère » de l'histoire. Histoire de l'art, 65:8.

ROZESTRATEN, Artur Simões. (2003). Estudo sobre a história dos modelos arquitetônicos na Antiguidade: origem e características das primeiras maquetes de arquiteto (Unpublished master's thesis). Universidade de São Paulo, São Paulo. 